\title{
EL MUNDO RURAL ANTE LA DESAMORTIZACIÓN GENERAL. LOS MODELOS DE LA ESPAÑA INTERIOR (CIUDAD REAL, 1855-1910) ${ }^{1}$
}

\author{
RURAL SOCIETY FACING THE GENERAL CONFISCATION. \\ PATTERNS OF THE INLAND SPAIN \\ (CIUDAD REAL, 1855-1910)
}

\author{
Ángel Ramón Del Valle Calzado \\ Universidad de Castilla-La Mancha
}

Entregado el 16-6-2014 y aceptado el 19-6-2015

\begin{abstract}
Resumen: Este estudio expone parte de los resultados de una investigación sobre la Desamortización General en la provincia de Ciudad Real, en la que las ventas alcanzaron un volumen considerable y, por lo tanto, tuvieron un impacto significativo. Se fundamenta en la consulta de un amplio abanico de fuentes (expedientes de subastas, protocolos, boletines de venta, libros de hacienda, censos electorales...) y en una metodología que intenta equilibrar los aspectos puramente cuantitativos con los cualitativos, siempre bajo la necesaria premisa de la construcción de modelos teóricos en base a comparativas con lo sucedido tanto a nivel regional como nacional.

Se persigue principalmente revelar qué grupos sociales adquirieron bienes, valorar las transformaciones sociales que ello supuso y evaluar la participación del mundo rural, especialmente de aquellos sectores vinculados a la tierra, en la desamortización. Y todo ello con dos objetivos: establecer un modelo encua-
\end{abstract}

\footnotetext{
1 Este artículo se enmarca en los proyectos de investigación «Familia, desigualdad y cambio generacional en la España centromeridional, siglos XVIII-XIX», referencia HAR2013-48901-C6-6-R, del Ministerio de Economía y Competitividad y «Conflicto social y protesta popular en Castilla-La Mancha, 1850-1950», referencia PEII-2014-24-P, de la Junta de Comunidades de Castilla-La Mancha.
} 
drado en la España interior y evaluar el papel de la desamortización en el proceso de formación de las élites agrarias en la España del siglo XIX y en la posible vinculación entre desamortización y caciquismo. En todo caso se debe subrayar que el resultado de nuestra investigación establece un modelo peculiar, incluso dentro del contexto geográfico regional, que permiten superar visiones e interpretaciones clásicas.

Palabras clave: España, Ciudad Real, Siglo XIX, desamortización, élites rurales, caciquismo.

\begin{abstract}
Is it possible to provide some novelties in regard to the disentailment process in Spain in 2014? We believe so. This paper aims to present a portion of the research results about the General Confiscation in Ciudad Real, the Spanish province where a higher number of estates were sold and, therefore, the place where most significant was its impact. This research is sustained over the analysis of a wide selection of documental sources, as well as a renewed methodology that doesn't focuses purely quantitative but qualitative aspects in a comparative frame. The principal aim consists in finding out those individuals who acquired properties, to appreciate the social transformations provoked by this process and to evaluate the rural society - especially the agrarian sectors - in the disentailment process to establish a regional model related to the inner Spain. The answers to this first question point to the second one: to connect the role of the confiscations in the local elites construction process in the $19^{\text {th }}$ Century Spain, as well as the bonds among local powers, spoils system and disentailment process. This allows to provide relevant conclusions regarding to the social consequences of disentailment process and, at de same time, to get over two pioneer works.
\end{abstract}

Key words: rural History, confiscation, peasantry, spoil system, $19^{\text {th }}$ century, Spain, Ciudad Real. 


\section{Introducción}

A lo largo de la década de los ochenta del siglo XX salieron a la luz numerosas monografías sobre la desamortización, que se vieron completadas poco después en los años noventa por los primeros balances generales $^{2}$, que han sido actualizados en algunos casos por los mismos autores más recientemente, aunque con la novedad de incluir modelos comparativos con otros países como Portugal, Francia y América Latina ${ }^{3}$. Y también pese a la sensación de agotamiento siguen apareciendo algunas monografías provinciales ${ }^{4}$. Aunque en el panorama actual de la historiografía española la desamortización ha dejado de ocupar una posición preeminente, aún hay extremos que necesitan ser abordados o bien porque se puede aportar cuestiones relevantes o bien porque aún hay áreas geográficas sin investigar o mal estudiadas.

Y este es nuestro caso. Nuestro ámbito de estudio, la provincia de Ciudad Real es, como veremos, una de las provincias donde más se desamortizó de toda España y, por lo tanto, merecedora de un análisis profundo. Por otra parte, los especialistas recordarán dos trabajos pioneros sobre esta provincia, que influyeron decisivamente en las primeras visiones sobre el proceso desamortizador, pero que estaban muy limitados en cuanto a sus fuentes y que durante largo tiempo han obstaculizado la realización de una investigación rigurosa. Con esta aportación

${ }^{2}$ German Rueda (ed.), La desamortización en la Península Ibérica, Marcial Pons, Madrid, 1993 y German Rueda, La desamortización en España: un balance (1766-1924), Arcolibros, Madrid, 1997.

3 Ver Bernard Bodinier, Rosa Congost y Pablo F. Luna (eds.), De la Iglesia al Estado. Las desamortizaciones de bienes eclesiásticos en Francia, España y América Latina, Prensas Universitarias de Zaragoza, Zaragoza, 2009, especialmente las aportaciones de Germán Rueda, «El proceso de la desamortización de bienes de origen eclesiástico (17691964) en España. Cuantificación y consecuencias socioeconómicas», pp. 177-204 y Josep Fontana, «Desamortización eclesiástica y reforma agraria liberal (España)», pp. 205222. En relación al marco comparativo, además de las ya citadas de German Rueda (ed.), La desamortización..., y la anterior, contamos también con la obra de Margarita Menegus y Mario Cerruti, La desamortización civil en México y España, 1750-1920, Senado de la República/Universidad Autónoma de Nuevo León/Universidad Nacional Autónoma de México, México, 2001.

${ }^{4}$ Dos de las más recientes son Félix González Marzo, La desamortización de Madoz en la provincia de Guadalajara, Caja de Ahorros de Guadalajara, Guadalajara, 2008 y Juan Pedro Vázquez Guzmán, La desamortización de Madoz en la provincia de Almería (18551936), Universidad de Almería, Almería, 2011. 
no sólo se mejoran esos primeros y parciales trabajos sino que se completa la tesis doctoral que en su día se realizó sobre la desamortización eclesiástica ${ }^{5}$. En fin, ningún tema está definitivamente cerrado y nunca está todo dicho. Como ha opinado Villares «no está de más revisitar este hecho histórico y replantear algunas de las grandes cuestiones que han nucleado tanto el proceso desamortizador como sus interpretaciones posteriores» ${ }^{6}$.

Una de las obsesiones de los historiadores de la desamortización es responder a la cuestión de quién se quedó con la tierra. Hace algunas décadas se subrayaba el protagonismo de sectores urbanos y burgueses, pero las más recientes monografías provinciales y síntesis generales han pasado a destacar el peso de diferentes grupos campesinos en las compras. Así, por ejemplo, Castrillejo Ibáñez hace de la participación campesina una de sus más importantes conclusiones ${ }^{7}$. Por esta razón, nuestra hipótesis de partida es el de comprobar la participación del mundo rural, especialmente de aquellos sectores vinculados a la tierra y establecer si es posible sus diferencias o similitudes con otras provincias del mismo marco territorial ${ }^{8}$. Las respuestas a esta primera hipótesis nos encaminan a una

5 Francisco Quirós Linares, «La desamortización, factor condicionante de la estructura de la propiedad agraria en el Valle de Alcudia y Campo de Calatrava», en Estudios Geográficos 96, 1964, pp. 367-407; Francisco Simón Segura, «La desamortización de 1855 en Ciudad Real», en Hacienda Pública Española 27, 1974, pp. 87-114 y Ángel Ramón del Valle Calzado, Desamortización y cambio social en La Mancha, 1836-1854, Instituto de Estudios Manchegos, Ciudad Real, 1996.

${ }^{6}$ Ramón Villares, «Reseña de Bernard Bodinier, Rosa Congost y Pablo F. Luna (eds.), De la Iglesia al Estado. Las desamortizaciones de bienes eclesiásticos en Francia, España y América Latina», en Historia Agraria, 54, 2011, p. 198.

${ }^{7}$ Félix Castrillejo Ibáñez, «Transformaciones en los grupos sociales de compradores, en Germán Rueda (ed.), La desamortización en la Península Ibérica, Marcial Pons, Madrid, pp. 250-251. La relación entre la reforma agraria liberal y el refuerzo de sectores campesinos se puede ver en Pegerto Saavedra y Ramón Villares (eds.), Señores y campesinos en la Península Ibérica, siglos XVIII-XX. 2. Campesinado y pequeña explotación, Crítica, Barcelona, 1991.

8 Ver Luís López Puerta, La desamortización eclesiástica de Mendizábal en la provincia de Guadalajara (1836-1851), Diputación Provincial de Guadalajara, Guadalajara, 1989; Antonio Díaz García, La desamortización en la provincia de Albacete (1836-1909), Instituto de Estudios Albacetenses, Albacete, 2001; Félix González Marzo, La desamortización eclesiástica de la tierra en la provincia de Cuenca, Diputación Provincial de Cuenca, Cuenca, 1985; Félix González Marzo, La desamortización de Madoz en la provincia de Cuenca (1855/1866), Diputación Provincial de Cuenca, Cuenca, 1993; Félix González Marzo, La desamortización de Madoz en la provincia de Guadalajara (1855-1896), 
segunda línea de trabajo, la de relacionar el papel de la desamortización en el proceso de formación de las élites locales, dado que la historiografía sobre las élites políticas ha asociado desamortización y caciquismo9 .

\section{Fuentes y tipología social de los compradores}

Se ha trabajado con un conjunto de fuentes, amplias pero complementarias, en continuo proceso de interrelación. Los expedientes de subastas se han contrastado con las escrituras de ventas de los protocolos notariales, los libros auxiliares de cuentas corrientes de compradores, los libros registro de fincas vendidas y las fuentes impresas (Boletín Oficial de la Provincia de Ciudad Real, Boletín Oficial de Ventas de Bienes Nacionales de la Provincia de Ciudad Real y Gaceta de Madrid ${ }^{10}$. Todo este caudal de información, organizado en una base de datos, nos permite, por un lado, realizar una cuantificación fiable y, por otro, identificar con alto grado de fiabilidad a los compradores, eliminando testaferros ${ }^{11}$, que per-

Caja de Ahorros de Guadalajara, Guadalajara, 2008; Vicente Rodríguez Rodríguez, La desamortización de Mendizábal en La Sagra, Caja de Ahorro de Toledo, Toledo, 1981; Julio Porres Martín-Cleto, La desamortización del siglo XIX en Toledo, Diputación Provincial de Toledo, 2001 (reedición de la de 1965) y Albino Feijoo Gómez, La Desamortización del siglo XIX en Castilla-La Mancha, Junta de Comunidades de Castilla-La Mancha, Toledo, 1990.

9 Para Ciudad Real, José María Barreda Fontes, Caciques y electores. Ciudad Real durante la Restauración, 1876-1923, Instituto de Estudios Manchegos, Ciudad Real, 1986 y para toda Castilla-La Mancha, Eduardo González Calleja y Javier Moreno Luzón, Elecciones y parlamentarios. Dos siglos de historia en Castilla-La Mancha, Junta de Comunidades, Toledo, 1993, especialmente pp. 188-196.

${ }_{10}$ El grueso de la investigación se ha llevado a cabo en el Archivo Histórico Provincial de Ciudad Real (en adelante AHPCR) en los fondos de desamortización (legajos 1-120), de Hacienda (libros 719-1213), de protocolos notariales (legajos 393-5286) y de prensa (legajos 27-35, 56-57 y 98). También el Archivo de la Diputación Provincial (en adelante ADCR), sobre todo, el Boletín Oficial de la Provincia y los libros de Actas, y diferentes archivos municipales (Almagro, Alcázar de San Juan, Daimiel, Bolaños, Valdepeñas y Ciudad Real entre otros) además de algunos fondos del Archivo Histórico Nacional y el Archivo del Ministerio de Hacienda.

11 A lo largo del todo el proceso se ha intentando identificar al comprador de las fincas, el que realizaba el pago del último plazo en los libros de cuentas corrientes. Seguramente en los casos que el dato del comprador se ha obtenido de otras fuentes es posible que aún se puedan encontrar algunos intermediarios. Recordad que conocemos la necesidad de ampliar la noción de «beneficiario» Fernando Sánchez Marroyo, «La desamortización como 
mita abordar un estudio social de los compradores en base, primero, a sus rasgos impersonales (vecindad/relación con la tierra y capacidad económica relacionada con su grado de inversión). Pero esto es insuficiente para un estudio socio-profesional. Había que buscar otras fuentes más productivas.

El primer paso fue exprimir al máximo los protocolos notariales con el objetivo de obtener datos profesionales de los compradores. Y el segundo explorar otras fuentes como los censos electorales, el Anuario Bailly-Baillère y el Indicador de Madrid de 1858. En cuanto a los primeros se ha trabajado con dos censos (1878 y 1890). El de 1878 recoge sólo a los ciudadanos con derecho al sufragio ${ }^{12}$, pero tiene la gran ventaja de reseñar su profesión. El de 1890 reúne ya a todos los varones mayores de edad y su profesión. También se han consultado los censos de 1857 y 1867, que nos permitía ubicar a los compradores que en ellos aparecían y de los que desconocíamos su profesión como miembros, al menos, de las clases medias. En relación al Anuario Bailly-Baillère, se ha usado la primera edición, la de $1879^{13}$ y el Indicador es una publicación similar, referida especialmente a Madrid ${ }^{14}$. En otras ocasiones hemos podido conocer la profesión u otros datos gracias a otras herramientas de manera más aleatoria ${ }^{15}$.

proceso dinámico: su contribución a la formación de la oligarquía agraria de la Restauración», en Desamortización y Hacienda Pública, Ministerio de Agricultura, Pesca y Alimentación, Madrid, 1986, vol. II, pp. 483-486 y Félix Castrillejo Ibañez, «Transformaciones..., pp. 213-214, pero seguimos el criterio de Francisco Tomás y Valiente ("El proceso de desamortización de la tierra en España”, en Agricultura y sociedad, 7, 1978, p. 21), que definía la figura del «beneficiario directo» como aquel que se beneficiaba de los precios y de las facilidades legales para adquirirlos.

${ }^{12}$ La nueva ley electoral de 1878 daba el voto a los contribuyentes de rústica de más de 25 pesetas y a los de Industrial de más de 50 pesetas además de las llamadas capacidades.

13 Anuario-almanaque del comercio, de la industria, de la Magistratura y de la Administración ó almanaque de las 400.000 señas de Madrid, de las provincias, de ultramar y de los Estados Hispano-Americanos con anuncios y referencias al comercio é industria extranjera, Bailly-Bailllière, Madrid, 1879.

${ }_{14}$ Francisco Domingo López, El indicador de Madrid para el año 1858, o sea Índice General de los principales habitantes, con las señas de sus habitaciones, así como de los contribuyentes y oficinas públicas y particulares, con un breve resumen de noticias de esta capital, Imprenta Nacional, Madrid, 1858.

15 Muy valiosa ha sido en este sentido la consulta de la edición digital del Boletín Oficial de la Provincia (disponible en http://www.uclm.es/Ceclm/index.htm), que nos permitía realizar búsquedas rápidas en el Boletín de manera que fuimos obteniendo datos de diferente carácter (social, profesional, político). 
El número total de compradores asciende a 2.395 (2.370 personas físicas y 25 sociedades). Se ha conseguido averiguar la profesión de 1.669, el $70 \%$ del total, una muestra muy representativa en la que se encuentran los participantes más significados (realizan el $81 \%$ de la inversión y se quedan con el $85,5 \%$ de la extensión vendida). De otros 129 no sabemos su profesión, pero sí que tenían derecho al voto. La calidad de la muestra da valor a las conclusiones, aunque se debe poner sobre la mesa un problema que ha de tenerse en cuenta: se ha intentado realizar la identificación profesional del comprador en los momentos previos a las compras, pero esto no ha sido posible en todos los casos. Es posible, por lo tanto, que la misma participación en el proceso desamortizador determine la profesión del comprador y es una cuestión que se ha intentado tener en cuenta a la hora de obtener las conclusiones.

Elaborar tipologías para estudiar procesos sociales es una tarea compleja, porque hacemos una foto fija de una realidad histórica dinámica. Por desgracia la historiografía desamortizadora no brilla por la construcción de tipologías con criterios teóricos nítidos, todo ello agravado además por su heterogénea variedad. A esta primera limitación se le suman las inherentes a las propias fuentes, que ofrecen cierta ambigüedad en alguna categoría profesional ${ }^{16}$. Para nuestra clasificación hemos tenido en cuenta algunos estudios clásicos, los más recientes centrados en el mismo ámbito geográfico, las síntesis generales y algunas monografías provinciales, especialmente en Castilla-La Mancha y Extremadura ${ }^{17}$. No obs-

${ }^{16}$ El problema principal es el relativo a la denominación usual, propietario, que no permite diferenciaciones internas. Se ha optado por combinar ese dato con otras variables (inversión total, derechos políticos, relación geográfica de las fincas con el domicilio y la cuota impositiva).

17 Ver José María Jover Zamora, «Situación social y poder político en la España de Isabel II», en Historia Social de España. Siglo XIX, Guadiana, Madrid, 1972. pp. 241-308 y Manuel Tuñón de Lara, Metodología de la historia social de España, Siglo XXI, Madrid, 1984, pp. 53-70. Para la región Carlos Panadero Moya, Sobre la estructura social de Albacete en tiempos de la Restauración, Instituto de Estudios Albacetenses, Albacete, 1983 y José María Barreda Fontes, Caciques y... En relación a las síntesis se toman como referencia a Germán Rueda, «El proceso de la desamortización de bienes de origen eclesiástico (17691964) en España. Cuantificación y consecuencias socioeconómicas», en Bernard Bodinier, Rosa Congost y Pablo F. Luna (eds.), De la Iglesia.., pp. 199-200 y Félix Castrillejo Ibáñez, «Transformaciones..., pp. 222-242. Ver nota 7 sobre las relativas a Castilla-La Mancha y para Extremadura, Juan García Pérez, Las desamortizaciones eclesiástica y civil en la provincia de Cáceres (1836-1870), Institución Cultural «El Brocense», Cáceres, 1994, pp. 147-192. 
tante, la base teórica proviene de las reflexiones de la última historiografía española sobre las elites del siglo XIX y se ha recurrido para realizarla a la integración de datos económicos, políticos y jurídicos ${ }^{18}$.

La clasificación está formada por cuatro grandes grupos. Los dos primeros (nobleza y clero) responden a criterios estamentales, aunque somos conscientes que ambos se integran en la sociedad del siglo XIX con criterios no estamentales, pero que aparecen diferenciados en la mayoría de las monografías y es vital conocer su grado de participación. Dentro de la nobleza se han distinguido a su vez dos subgrupos, el de la nobleza titulada residente fuera de la provincia y el de la nobleza local, que a efectos posteriores de análisis, se integra dentro de los grupos rurales vinculados a la tierra. Los dos restantes nos permiten responder a los interrogantes que nos planteábamos al principio y para su delimitación se usa el criterio de vecindad. El primero está formado por compradores urbanos y foráneos, integrados por vecinos de Madrid y de otras grandes ciudades. El segundo agrupa a los compradores rurales, los que residen en la propia provincia y en localidades aledañas a la misma. Es el más amplio y su complejidad hace necesario subdividirlo en tres subgrupos, uno para los compradores rurales vinculados a la tierra (propietarios y campesinos - labradores, arrendatarios y jornaleros -), otro para los rurales no agrarios (comerciantes e industriales, profesiones liberales, funcionarios, militares) y el último para los individuos rurales y populares no vinculados a la tierra (artesanos, empleados y obreros no agrarios).

\section{Ciudad Real en el tránsito al régimen liberal: una economía agraria y una sociedad polarizada}

La actual provincia de Ciudad Real, una de las más extensas de España, es un territorio que suele identificarse con La Mancha. Pero Ciudad Real no es sólo La Mancha, llana y con escaso arbolado. Buena parte del norte, oeste y sur de la provincia tiene un relieve montañoso, formado por un conjunto de media-baja montaña configurado por los Montes de Toledo al norte (comarca Montes-Norte), por los Montes del Oeste lindando con Extremadura (comarca Montes-Sur) y por Sierra Morena al sur (co-

18 Seguimos especialmente las reflexiones de Juan Pro Ruiz, «Las élites de la España liberal: clases y redes en la definición del espacio social», en Historia Social, 21, 1995 , pp. 47-69. 
marca Pastos), donde aparecen una serie de valles, entre ellos, el de Alcudia, con una personalidad física propia. A mediados del siglo XVIII sobresalían las tierras ocupadas por pastos (montes, dehesas y prados, 45,9\%) frente a las de labor $(27,7 \%)$, dedicadas mayoritariamente al cereal de secano $^{19}$. En fin, una economía de Pastos y dehesas, clave para la ganadería trashumante.

La sociedad del Antiguo Régimen rural se caracterizaba por su grado de polarización con un elevado nivel de concentración de la propiedad y con un escaso peso de la comunidad campesina en la vertebración de las actividades agropecuarias. Las comarcas que quedaron bajo el dominio concejil (Montes de Toledo) y de la Orden de Calatrava desde el centro de la provincia (Campo de Calatrava) hasta el oeste extremeño y el sur andaluz (Valle de Alcudia, Montes Sur) forman un área donde predomina la gran propiedad. Así, por ejemplo, en Corral de Calatrava, seis propietarios acumulaban el $41 \%$ de la tierra, mientras el $54 \%$ de los hogares no poseía nada ${ }^{20}$. Por el contrario en las zonas dominadas por la Orden de San Juan (La Mancha) y de Santiago (Campo de Montiel) la gran propiedad es menos relevante, lo que no significa sino algo menos de desigualdad. En Alcázar de San Juan los pequeños labradores ocupaban algo más del $26 \%$ de la tierra, pero el $70 \%$ de la población no poseía alguna propiedad rústica alguna, mientras la Iglesia y los labradores ricos poseían ese mismo porcentaje $^{21}$. Con algunas diferencias comarcales la distribución de la tierra estaba desequilibrada. Iglesia, concejos y una pequeña elite rural poseían la inmensa propiedad de la tierra. López-Salazar realizó una radiografía en forma de pirámide invertida: los principales, los de mediano pasar y los que poco pueden ${ }^{22}$. Grandes propiedades y minifundismo cam-

19 Francisco García González y Cosme J. Gómez Carrasco, «Tierra y sociedad rural en Castilla-La Mancha a finales del Antiguo Régimen», en Ángel Ramón del Valle Calzado (coord.), Historia agraria de Castilla-La Mancha, siglos XIX-XXI, Almud, Ciudad Real, 2010, p. 84.

20 Francisco García González y Cosme J. Gómez Carrasco, «Tierra y sociedad..., pp. 105-113 y F. García González, «Corral de Calatrava en el siglo XVIII. Familia, población y sociedad», en Francisco Alía Miranda y Antonio de Juan (coords.), Centenario del Cardenal Monescillo. Vol. II. Corral de Calatrava, UCLM, Cuenca, 1997, pp. 83-124.

21 Javier Donézar Díez de Ulzurrum, Riqueza y propiedad en la Castilla del Antiguo Régimen. La provincia de Toledo en el siglo XVIII, Ministerio de Agricultura, Madrid, 1984, p. 311 .

22 Jerónimo López-Salazar Pérez, Estructuras agrarias y sociedad rural en la Mancha (s. XVI-XVII), Instituto de Estudios Manchegos, Ciudad Real, 1986, pp. 309-532. 
pesino serán las tónicas dominantes. Los mayores propietarios gestionan además las dehesas concejiles, las tierras de las Órdenes y de la nobleza foránea, mientras la masa campesina y jornalera vivía al borde de la subsistencia. A lo largo del Antiguo Régimen el proceso de concentración de la propiedad se agravó y a la altura de mediados del siglo XIX esta situación había variado poco, dado que en la Estadística de 1855 el 4,7 \% de los contribuyentes, 2.523, eran grandes contribuyentes frente al $62 \%$ de ínfimos y el $33 \%$ de medianos ${ }^{23}$.

El censo de población de 1860 confirma esta configuración. La población provincial era analfabeta ( $82 \%$ ) y se dedicaba de manera generalizada al sector primario (el $75 \%$ de la población activa). La mayor parte de la misma, cerca del $60 \%$, eran obreros, fundamentalmente agrarios (los obreros no agrarios suponen únicamente un $4,1 \%$ de ese porcentaje). Los propietarios y arrendatarios suman el $21 \%$ de la población activa. Los sectores no agrarios (artesanos, comerciantes, fabricantes e industriales, profesionales y funcionarios) tienen escaso peso cuantitativa y cualitativamente.

En conclusión, las características esenciales de la sociedad manchega del XIX (altas tasas de analfabetismo, relevancia de grupos sociales rurales con escasa capacidad económica, limitada presencia de la burguesía comercial, industrial o profesional, poco número de funcionarios) definen una sociedad agraria y desigual.

\section{La desamortización en cifras}

La Desamortización General puso en venta una gran cantidad de tierra (8.819 fincas con un total de 701.791 hectáreas), de la que finalmente se vendió el $99 \%$ (8.516 fincas y 693.435 hectáreas) ${ }^{24}$. Esto supone un enorme trasvase de propiedad agraria. Los bienes rústicos vendidos fueron tasados en algo más de ciento veintisiete millones de reales y rematados en doscientos tres millones, con una cotización del $160 \%$, por lo que,

${ }^{23}$ Los datos de la estadística en Luís E. Esteban Barahona, Agricultura y ganadería en Ciudad Real. Siglos XIX y XX, Biblioteca de Autores Manchegos, Ciudad Real, p. 124.

${ }^{24}$ Nos referimos siempre a bienes vendidos realmente. Están descontadas las fincas que no llegaron a venderse por cualquier razón. Debemos subrayar además que la tierra desamortizada supone más cantidad de tierra que la superficie agrícola en 1860 (633.923 has.) y el $38,4 \%$ de la superficie agraria útil, un porcentaje muy considerable (los datos de la superficie en Luís E. Esteban Barahona, Agricultura y ganadería..., p. 28). 
en teoría, se obtuvo un beneficio bruto de setenta y seis millones de reales. Los estudios de Simón Segura y Quirós Linares evaluaron el proceso a la baja, dado que el primero afirmaba que se habían vendido casi noventa mil hectáreas menos y el segundo, referido sólo a una comarca, en treinta y seis mil hectáreas menos. Si a lo vendido a partir de 1855 le sumamos de la etapa anterior, la extensión final vendida fue de 748.856 hectáreas, una cantidad impresionante ${ }^{25}$. Lo desamortizado en Ciudad Real supone prácticamente la mitad del total regional (el $47 \%$ ) y evidencia la excepcional importancia que el proceso desamortizador alcanzó en Ciudad Real frente al resto de provincias castellano-manchegas.

\section{Tabla 1}

Bienes rústicos vendidos en Castilla-La Mancha, 1836-1924

\begin{tabular}{lrrrrc}
\hline \multicolumn{1}{c}{ Provincia } & Fincas & Has. & \multicolumn{1}{c}{ Tasación } & \multicolumn{1}{c}{ Remate } & Cotización \\
\hline Albacete & 4.033 & 250.517 & 36.088 .436 & 72.032 .518 & 199,9 \\
Ciudad Real & 13.046 & 748.856 & 145.389 .266 & 256.558 .150 & 176,5 \\
Cuenca & 4.651 & 179.435 & 35.798 .935 & 72.522 .205 & 202,5 \\
Guadalajara & 84.464 & 189.445 & 53.579 .456 & 145.789 .044 & 272,0 \\
Toledo & 2.962 & 229.074 & 76.456 .997 & 222.967 .930 & 291,6 \\
\hline TOTAL & 109.156 & 1.597 .327 & 347.313 .090 & 769.869 .847 & 221,7 \\
\hline
\end{tabular}

Fuente: Para Albacete (Antonio Díaz García, La desamortización... Para Cuenca (Félix González Marzo, La desamortización ..., y La desamortización de Madoz...). Para Guadalajara (Luís López Puerta, La desamortización eclesiástica ... y Félix González Marzo, La desamortización de Madoz...). Para Toledo (Vicente Rodríguez Rodríguez, La desamortización de Mendizábal...; Julio Porres Martín-Cleto, La desamortización del... y Albino Feijoo Gómez, La desamortización del siglo XIX.... Para Ciudad Real (Ángel Ramón del Valle Calzado, Desamortización y..., y AHPCR, expedientes de subastas, fondos de Hacienda, protocolos notariales y fuentes impresas).

Pero también a nivel nacional. Sólo tres regiones en su conjunto (Extremadura, Castilla-León y Andalucía) superan lo vendido en esta provin-

25 Francisco Quirós Linares, «La desamortización, factor..., p. 389; Francisco Simón Segura, «La desamortización..., pp. 95-97 y Ángel Ramón del Valle Calzado, Desamortización y..., p. 54. 
cia. Por poner un ejemplo concreto: en toda Andalucía sólo se vendieron cincuenta mil hectáreas más que en Ciudad Real y la extensión vendida aquí supone el 13,3\% del total nacional ${ }^{26}$. Recordar para evaluar la importancia de las cifras que, por ejemplo, en la Francia revolucionaria (17901797) se puso en venta en torno al $9 \%$ de la superficie nacional, un porcentaje parecido al español, pero lejano al de Castilla-La Mancha o al de la provincia de Ciudad Real ${ }^{27}$. En conclusión, Ciudad Real fue la provincia de España donde más tierra se trasvasó. Sólo las extremeñas se acercan. Por ejemplo, en Cáceres se desamortizó algo más de 740.000 hectáreas y en la de Badajoz 560.000 hectáreas ${ }^{28}$. Queda demostrado, por tanto, su relevancia en el proceso desamortizador a nivel regional y nacional.

\section{Los beneficiarios: cuantificación, relevancia, procedencia y grado de vinculación con la tierra}

Una de las cuestiones que se ha debatido en torno a la desamortización ha sido la de valorar si esta supuso un incremento del número de propietarios. Si ponemos en relación el número de compradores (2.395) con la población de 1860 , esa cifra supone un irrelevante $1,0 \%$, que se eleva al 4,9\% si consideramos la población activa agraria masculina o al 5,3\% al compararlo con el número de contribuyentes de rústica de 1855 . No parece que el número de propietarios, por tanto, se incrementase de manera significativa, lo que contrasta con lo sucedido en buena parte de España donde si se produjo dicho aumento. E igualmente difiere del caso francés donde uno de cada diez hogares pudo favorecerse de la compra de tierras y si presenta más similitudes con el caso portugués donde «no hubo un ensanchamiento significativo de la clase de propietarios» ${ }^{29}$.

26 Juan García Pérez, «Efectos de la desamortización sobre la propiedad y los cultivos», en Germán Rueda (ed.), La desamortización en la Península Ibérica, Marcial Pons, Madrid, 1993, pp. 171-173.

27 Bernard Bodinier, «El problema agrario en la Revolución Francesa: abolición del feudalismo y nacionalizaciones», en Bernard Bodinier, Rosa Congost y Pablo F. Luna (eds.), De la Iglesia..., p. 163.

28 Juan García Pérez, Las desamortizaciones..., pp. 30-31.

${ }^{29}$ Félix Castrillejo Ibáñez, «Transformaciones.., p. 250; Bernard Bodinier, «El problema agrario..., p. 165 y Luis Espinha da Silveira, «La desamortización en Portugal», en G. Rueda (ed.), La desamortización en la Península Ibérica, Marcial Pons, Madrid, 193, p. 57. 


\section{Tabla 2}

Compradores y vecindad

\begin{tabular}{lccc}
\hline \multicolumn{1}{c}{ Vecindad } & \% Compradores & \% Sup. & \% Remate \\
\hline Provincia & 90,5 & 55,3 & 45,1 \\
Madrid & 6,3 & 38,4 & 45,5 \\
Otras Provincias & 2,5 & 5,6 & 8,6 \\
Desconocida & 0,7 & 0,7 & 0,8 \\
\hline
\end{tabular}

Fuente: AHPCR, expedientes de subastas, fondos de Hacienda, protocolos notariales y fuentes impresas.

\section{Tabla 3}

Los compradores provinciales según su vecindad

\begin{tabular}{lccrc}
\hline \multirow{2}{*}{ Lugar Vecindad } & \multicolumn{2}{c}{ Compradores } & $\begin{array}{c}\% \\
\text { Remate }\end{array}$ & $\begin{array}{c}\% \\
\text { Extensión }\end{array}$ \\
\cline { 2 - 3 } & Número & \% total & & \\
\hline Ciudad Real & 226 & 9,4 & 5,8 & 5,8 \\
C. Partido & 657 & 27,4 & 13,6 & 17,7 \\
Resto Provincia & 1.285 & 53,6 & 25,7 & 31,8 \\
\hline
\end{tabular}

Fuente: AHPCR, expedientes de subastas, fondos de Hacienda, protocolos notariales y fuentes impresas. \% en relación al total de compradores.

\section{Tabla 4}

Origen de los grandes compradores

\begin{tabular}{lcrr}
\hline \multicolumn{1}{c}{ Origen } & Compradores & Hectáreas & \multicolumn{1}{c}{ Remate rs. } \\
\hline Madrid & 34 & 145.606 & 74.433 .382 \\
Otras provincias & 5 & 8.784 & 8.671 .960 \\
Ciudad Real & 25 & 95.600 & 24.679 .114 \\
\hline Total & 64 & 249.997 & 105.784 .456 \\
\hline
\end{tabular}

Fuente: AHPCR, expedientes de subastas, fondos de Hacienda, protocolos notariales y fuentes impresas. 
¿Favoreció más a grupos urbanos o rurales? Los primeros estudios sobre la desamortización incidieron en dos aspectos, ambos interrelacionados: el carácter urbano y burgués de los más importantes núcleos de beneficiarios. Fue Fontana quien lo resumía en el encanto que tenían los compradores madrileños: «lo que sucede es que suelen llamar sobre todo la atención unos pocos compradores, con frecuencia especuladores residentes en Madrid» ${ }^{30}$ y a partir de entonces diferentes monografías ponían de relieve la idea contraria: «cada vez parece más claro el peso de la participación campesina en contra de la opinión generalizada de un exclusivo protagonismo de las urbanas, y en especial de la madrileña» ${ }^{31}$. ¿Qué pasó exactamente en la provincia de Ciudad Real?

Si tenemos en cuenta el número de compradores, está claro que la participación de los residentes en la provincia fue más alta que la del resto ${ }^{32}$. $\mathrm{Si}$, por el contrario, evaluamos también la inversión y la extensión adquirida, se observa una polarización entre estos y los madrileños. Los compradores de otras provincias participaron en menor medida, aunque sus adquisiciones son cuantitativamente importantes. Los provinciales forman el núcleo más numeroso (2.168), se quedaron con la mitad de la superficie vendida e invirtieron un porcentaje algo menor ${ }^{33}$. El grupo de beneficiarios más numeroso es el de aquellos que viven en medianos y pequeños municipios por lo que queda probada también la participación de la población rural, al conseguir casi el $32 \%$ de la tierra desamortizada. Los compradores de la capital de la provincia y de las cabeceras de partido son también relevantes. Entre ambos reúnen el $37 \%$ de los beneficiarios y se quedan con casi el $24 \%$ de las tierras desamortizadas.

30 Josep Fontana, «La desamortización de Mendizábal y sus antecedentes», en Ángel García Sanz y Ramón Garrabou (eds.), Historia agraria de la España contemporánea. I, Crítica, Madrid, 1985, p. 238.

31 Félix Castrillejo Ibáñez, «Transformaciones..., p. 250.

32 Se ha optado por obviar la típica separación entre urbano y rural en base a un número de habitantes. Consideramos que en esta provincia no existen núcleos urbanos como tales y, por ello, se separan en cuatro grupos: vecinos de la provincia, de Madrid, de otras provincias $\mathrm{y}$, finalmente, el compuesto por lo que no conocemos su vecindad.

33 El grupo de las cabeceras de partido judicial son Almagro, Alcázar de San Juan, Almadén, Almodóvar del Campo, Daimiel, Manzanares, Piedrabuena, Valdepeñas y Villanueva de los Infantes, que tienen unos rasgos comunes: mayoritaria dedicación agrícola, población más numerosa y centros políticos donde se vota, se juzga y se pueden comprar bienes nacionales. 
En este sentido lo sucedido en esta provincia viene, por un lado, a confirmar que la hipótesis de la historiografía desamortizadora de los primeros años setenta y ochenta no estaba errada del todo pero, por otro, también lo apuntado en las últimas síntesis sobre el protagonismo de algunos grupos sociales rurales. Ambas llevan en parte razón. Un grupo no excluye al otro. No obstante, si a este análisis le añadimos algunos datos sobre la extensión adquirida y la inversión realizada por cada uno de ellos podemos matizar esta primera conclusión.

La mayoría de los compradores (1.643, casi el $70 \%$ ) son pequeños compradores, pues sólo se reparten algo más de 16.000 hectáreas. La inmensa mayoría de estos son rurales. Por el contrario, un pequeño núcleo de grandes compradores (177 individuos, el 7,6 \%) compró casi quinientas mil hectáreas y realizó el $60 \%$ de la inversión. Si combinamos dos parámetros (extensión e inversión ${ }^{34}$ ) el grupo se reduce aún más, a 64 individuos (el 2,7 \%), que se quedaron con doscientas cincuenta mil hectáreas e invirtieron ciento cinco millones de reales. Y entre estos el peso de los madrileños es mayor. En fin compraron tanto individuos rurales como sectores de la burguesía urbana, aunque en diferente grado y amplitud.

\section{Grupos sociales y desamortización. Una visión general}

La tabla 5 resume la participación de los diferentes grupos sociales teniendo en cuenta sólo a los compradores de los se ha podido conocer su profesión. Se observan con nitidez dos grandes bloques. Por un lado, los compradores rurales agrarios que agrupan a la mayor parte de los beneficiarios. Se quedaron con cerca del $37 \%$ de la extensión vendida y realizaron un esfuerzo inversor relevante. La importancia de este bloque aumenta si le sumamos a la nobleza local, dado que estos están vinculados a la tierra y se denominan profesionalmente como propietarios. Así juntos superan el $45 \%$ de la superficie y el $40 \%$ de la inversión. reales.

${ }^{34}$ Aquellos que compran más de 1.000 hectáreas o invierten más medio millón de 


\section{Tabla 5}

Grupos sociales y desamortización

\begin{tabular}{|c|c|c|c|c|c|c|}
\hline \multirow{2}{*}{ Grupo social } & \multicolumn{2}{|c|}{ Compradores } & \multicolumn{2}{|c|}{ Inversión } & \multicolumn{2}{|c|}{ Extensión } \\
\hline & N. ${ }^{\circ}$ & $\%$ & Rs. & $\%$ & Has. & $\%$ \\
\hline Nobleza: & 85 & 5,1 & 21.491.160 & 12,5 & 73.501 & 12,4 \\
\hline Foránea & 7 & 0,4 & 3.450 .312 & 2,0 & 19.994 & 3,4 \\
\hline Local & 78 & 4,7 & 18.030 .848 & 10,5 & 53.507 & 9,0 \\
\hline Clero & 19 & 1,1 & 531.479 & 0,3 & 2.705 & 0,4 \\
\hline $\begin{array}{l}\text { Compradores urbanos: } \\
\text { burguesía madrileña }\end{array}$ & 103 & 6,2 & 75.902 .785 & 44,2 & 221.583 & 37,4 \\
\hline Banqueros y financieros & 29 & 1,7 & 38.368 .557 & 22,3 & 106.176 & 17,9 \\
\hline Propietarios & 21 & 1,2 & 19.475 .514 & 11,3 & 36.796 & 6,2 \\
\hline Profesiones Liberales & 28 & 1,7 & 8.870 .225 & 5,2 & 26.157 & 4,4 \\
\hline Políticos y militares & 7 & 0,4 & 2.412 .986 & 1,4 & 15.507 & 2,6 \\
\hline Funcionarios & 4 & 0,2 & 3.272 .367 & 1,9 & 14.307 & 2,4 \\
\hline $\begin{array}{l}\text { Comerciantes } \\
\text { e Industriales }\end{array}$ & 8 & 0,5 & 2.966 .023 & 1,7 & 12.300 & 2,1 \\
\hline $\begin{array}{l}\text { Empleados empresas } \\
\text { privadas }\end{array}$ & 6 & 0,3 & 537.113 & 0,3 & 10.340 & 1,7 \\
\hline Compradores rurales: & 1.462 & 87,6 & 73.694.366 & 42,9 & 293.851 & 49,7 \\
\hline A) Grupos rurales agrarios & 1.098 & 65,8 & 51.551.504 & 30,0 & 216.018 & 36,5 \\
\hline a) Propietarios & 816 & 48,9 & 41.066 .855 & 23,9 & 148.866 & 25,2 \\
\hline b) Campesinado & 259 & 15,5 & 2.118.733 & 1,2 & 15.024 & 2,6 \\
\hline Labradores & 217 & 13,1 & 1.838 .020 & 1,0 & 14.120 & 2,4 \\
\hline Arrendatarios & 5 & 0,3 & 162.800 & 0,1 & 212 & 0,03 \\
\hline Jornaleros & 36 & 2,1 & 110.913 & 0,06 & 464 & 0,07 \\
\hline Ayuntamientos & 1 & 0,05 & 7.000 & 0,004 & 228 & 0,04 \\
\hline $\begin{array}{l}\text { c) Sociedades } \\
\text { de compra }\end{array}$ & 23 & 1,4 & 8.365 .916 & 4,9 & 52.128 & 8,8 \\
\hline
\end{tabular}




\begin{tabular}{|c|c|c|c|c|c|c|}
\hline \multirow{2}{*}{ Grupo social } & \multicolumn{2}{|c|}{ Compradores } & \multicolumn{2}{|c|}{ Inversión } & \multicolumn{2}{|c|}{ Extensión } \\
\hline & N. ${ }^{\circ}$ & $\%$ & Rs. & $\%$ & Has. & $\%$ \\
\hline $\begin{array}{l}\text { B) Grupos rurales no agra- } \\
\text { rios: la burguesía local }\end{array}$ & 242 & 14,5 & 20.649 .579 & 12,0 & 72.171 & 12,2 \\
\hline Profesiones liberales & 136 & 8,1 & 9.827 .136 & 5,7 & 36.398 & 6,1 \\
\hline $\begin{array}{l}\text { Comerciantes/ } \\
\text { Industriales }\end{array}$ & 67 & 4,0 & 7.664 .870 & 4,4 & 23.401 & 3,9 \\
\hline Funcionarios & 31 & 1,8 & 2.470 .905 & 1,4 & 8.890 & 1,5 \\
\hline Militares & 6 & 0,3 & 655.688 & 0,4 & 2.210 & 0,4 \\
\hline Estudiantes & 2 & 0,1 & 30.980 & 0,01 & 1.272 & 0,2 \\
\hline $\begin{array}{l}\text { C) Grupos medios-bajos } \\
\text { no agrarios }\end{array}$ & 122 & 7,3 & 1.493 .283 & 0,9 & 5.662 & 1,0 \\
\hline Artesanos & 82 & 4,9 & 854.304 & 0,5 & 3.741 & 0,6 \\
\hline Empleados & 29 & 1,7 & 621.353 & 0,4 & 1.882 & 0,3 \\
\hline Obreros no agrarios & 11 & 0,6 & 17.626 & 0,01 & 39 & 0,006 \\
\hline TOTAL & 1.669 & & 171.619.790 & & 591.640 & \\
\hline
\end{tabular}

Fuente: AHPCR, expedientes de subastas, fondos de Hacienda, protocolos notariales y fuentes impresas. \% en relación a los totales de los compradores identificados profesionalmente.

Por otro, la burguesía urbana residente principalmente en Madrid que presenta porcentajes similares (37,4\% extensión y 44,2 de la inversión). Hay una diferencia significativa entre ambos: mientras un grupo concentra el $70 \%$ de los beneficiarios, el otro sólo está constituido por cien personas. Es evidente que los urbanos que participan son una minoría, pero hicieron grandes compras, convirtiéndose en grandes propietarios de tierra. Esto no hace sino confirmar la conclusión ya señalada anteriormente: la desamortización favoreció a un sector muy concreto de la burguesía urbana madrileña, pero también de manera algo más amplia a la burguesía agraria local.

En el caso concreto de los rurales, junto a los grupos ligados a la tierra aparecen sectores de la burguesía local. No llegan a los niveles de los dos bloques anteriores, pero si tienen una participación subrayable. Finalmente se comprueba también que los sectores rurales-no agrarios más po- 
pulares (artesanos, empleados y obreros) estuvieron excluidos y su participación es testimonial. Los mecanismos legales del proceso y el hecho de que las fincas subastadas fueron en muchos casos de grandes dimensiones y alta tasación vedaron el acceso a la propiedad agraria a los sectores más modestos.

¿Cómo participaron la nobleza y el clero en la desamortización? La participación del clero es residual y sólo hemos localizado algunos casos puntuales, normalmente curas párrocos. Algo parecido ocurre con la nobleza titulada foránea. Sólo siete titulados realizan compras más bien modestas y, por lo tanto, la pervivencia de algunos de estos nobles en las listas de mayores contribuyentes en la provincia no se debe ni mucho menos a la desamortización. Por el contrario, la nobleza local si que participó de manera notable, de manera que forman uno de los grupos más importante con una media superior a las seiscientas ochenta hectáreas y una inversión de más de doscientos treinta y un mil reales por comprador. Es evidente que sectores concretos de la nobleza local se favorecieron notablemente del proceso desamortizador y fue un factor decisivo en su continuidad como parte de las elites liberales.

En relación a lo sucedido en la época de Mendizábal en esta misma provincia esta configuración es diferente, porque si bien se mantiene el protagonismo de la burguesía madrileña, en la época de Madoz aumenta exponencialmente el de los propietarios y de la nobleza local, mientras la burguesía provincial (comerciantes e industriales, profesionales liberales y funcionarios) aún manteniendo cierta participación subrayable pierde protagonismo ${ }^{35}$.

\section{El mundo rural y la desamortización}

\subsection{Los propietarios: la burguesía agraria local}

Ya hemos comprobado la relevante trascendencia del mundo rural vinculado a la explotación de la tierra en la desamortización. Ahora bien esto es una afirmación muy genérica y equívoca. Los datos parecen señalar en una clara dirección: el protagonismo de los denominados propieta-

35 Ángel Ramón del Valle Calzado, Desamortización y..., pp. 50-69. 
rios $^{36}$, que se quedan con el 25,2\% de la extensión vendida, casi 150.000 hectáreas. No obstante hay que subrayar que la inmensa mayoría fueron pequeños compradores, dado que el $80 \%$ (640) invirtió menos de 50.000 reales y el $57 \%$ adquirió menos de veinte hectáreas. Por el contrario, un núcleo significativo compuesto por 137 propietarios realizó grandes inversiones al comprar más de 200 hectáreas cada uno y quedarse con el 86 $\%$ de la extensión adquirida por este grupo. Fue este núcleo el que aprovechó la desamortización a fondo para crear un sólido patrimonio rústico e incorporarse a la primera fila de la burguesía agraria que nace con la desamortización.

La cuantía de sus cuotas impositivas demuestran que la desamortización favoreció principalmente al segmento medio-alto de los propietarios, aquellos que superaban la barrera que marcaba la ley para poder votar $y$, de esta manera, contribuyó a reforzar a una capa más amplia de propietarios acomodados y a un pequeño grupo de grandes propietarios $^{37}$. Pero sus nombres no sólo aparecen como compradores sino que también copan los primeros lugares en las listas de mayores contribuyentes y ocupan el poder local. Del conjunto formado por el primer mayor contribuyente de cada localidad en 1877 resulta que 75 de ellos son propietarios frente a sólo 16 labradores y 2 miembros de las profesiones liberales - un médico y un abogado, a su vez, propietarios -). De estos casi el $70 \%$ (52) son compradores en la Desamortización General por lo que es clara la relación entre ambos hechos. El peso de los compradores como mayores contribuyentes es importante en todas las poblaciones, pero sobresale en las más pequeñas. En treinta y dos pequeñas poblaciones encontramos entre los tres primeros mayores contribuyentes

36 Aunque el concepto de propietario es muy poliédrico creemos que en el siglo XIX tenía una significación de prestigio social. Los propietarios, aunque llevasen la explotación de sus tierras, solían utilizar mano de obra jornalera u otras fórmulas de arrendamiento.

37 Hemos recopilado las cuotas impositivas que aparecen en los censos electorales (Censo electoral de 1877 - BOPCR, de 9/11/1877 - y de 1890 - BOPCR de 8/1/1890 - ). Hemos localizado la cuota de 653 (81,5\% del total). La mayoría eran pequeños contribuyentes, el $63 \%$, pues pagan menos de 300 pesetas. Un grupo intermedio esta formado por 181 compradores, los que pagan entre 300 y 1.000 pesetas, y representan el 27,7 \%. Sólo un $9,3 \%$ de estos propietarios (60) pagaban más de 1.000 pesetas y por lo tanto eran grandes contribuyentes (se han seguido los criterios de división de Carlos Panadero Moya, Sobre la estructura..., p. 30 y Manuel Tuñón de Lara, Estudios sobre el siglo XIX español, Madrid, 1976, p. 160). 
a propietarios que habían participado en la desamortización ${ }^{38}$. También aparecen ligados al poder local como alcaldes o como concejales, como jueces municipales o como miembros de las juntas periciales y de las juntas municipales de asociados ${ }^{39}$. Y un número significativo de ellos llegó a la Diputación Provincial. Hasta veintiocho de estos propietarios fueron diputados provinciales ${ }^{40}$, aunque ninguno consiguió un escaño ni el Congreso ni en el Senado.

En conclusión, la desamortización favoreció principalmente a este segmento concreto, que va a formar un eslabón intermedio dentro de la nueva burguesía agraria, estrechamente imbricado con el poder local. Se configura así una élite local, reforzada por la desamortización a nivel económico y por la configuración política del Estado liberal a nivel político.

Además debemos de tener en cuenta que buena parte de lo adquirido por las sociedades de compra se puede adscribir a este grupo, dado que la más importante de estas sociedades estuvo formada por propietarios. Se trata de la «Sociedad Compradora del Término Municipal de Almodóvar del Campo», formada por 16 individuos, cuyo objetivo fue comprar tierras desamortizadas para venderlas y repartirse los beneficios. Así llegaron a adquirir 40.695 hectáreas, lo que supone el 78 \% de la tierra comprada por todas las sociedades ${ }^{41}$.

Igualmente la nobleza local se puede integrar con los propietarios. Sectores concretos de la nobleza local se favorecieron notablemente del

38 Son Villarta, Fuente el Fresno, Abenojar, Agudo, Alamillo, Aldea del Rey, Almadén, Cabezarrubias, Carrizosa, Corral, Los Pozuelos, Villamayor, Bolaños, Alcolea, Anchuras, Ballesteros, Cañada, Fernancaballero, Fontanarejo, Luciana, Picón, Poblete, Porzuna, Albadalejo, Alhambra, Almedina, Hinojosas, Montiel, Puebla del Príncipe, Terrinches, Torre de Juan Abad y Villanueva de la Fuente.

${ }^{39}$ La consulta del Boletín Oficial de la Provincia nos permite concretar esta realidad. La presencia de los compradores en sus páginas resulta en ocasiones abrumadora. La reciente digitalización del mismo por el Centro de Estudios de Castilla-La Mancha que permite búsquedas rápidas, ha facilitado la comprobación de esta relación.

40 Ángel Ramón del Valle Calzado y Rafael Villena Espinosa, «Diputación y estado liberal (1833-1874», en Isidro Sánchez Sánchez (coord.), Historia de la Diputación Provincial de Ciudad Real (1835-1999), Diputación Provincial, Ciudad Real, pp. 188-189 y Manuel Requena Gallego, «Vida política», en Isidro Sánchez Sánchez (coord.), Historia..., pp. 188-189 y 202-204.

${ }^{41}$ El estudio concreto de la actuación de esta sociedad está siendo objeto de estudio de una tesis doctoral por lo que aquí sólo se concretan algunos aspectos muy concretos de la misma. 
proceso desamortizador y fue un factor decisivo en su continuidad como parte de las elites locales. En el Antiguo Régimen sobresalía por formar una sólida oligarquía económica, con una estructura patrimonial basada en haciendas mixtas agrícolas-ganaderas con pocas tierras y alta capacidad de labranza ${ }^{42}$. López-Salazar destaca su incrementó en el siglo XVI y su progresivo ascenso social mediante diversas estrategias como el servicio a la Corona, la obtención de hábitos de las Órdenes Militares o de algún título de nobleza ${ }^{43}$, la presencia en los ayuntamientos y, sobre todo, por las alianzas familiares mediante sus muy frecuentes lazos matrimoniales ${ }^{44}$. Buena parte de esta hidalguía aprovechó la desamortización para consolidar su posición de gran propietaria, primero más tímidamente en la etapa eclesiástica y de una forma más generalizada en la Desamortización General. Si volvemos a la tabla 5 y recordamos algunas de las cifras allí expuestas comprobamos como esta fracción local de la nobleza va a tener una relevancia significativa. En total pertenecen al mismo 78 personas, cuyas compras en porcentaje se sitúan en torno al diez por ciento del total de los compradores identificados profesionalmente. En realidad este conjunto de compradores se reducen a unas veinte y cinco familias, que formaran como veremos el núcleo central de las elites agrarias durante la Restauración ${ }^{45}$.

Aunque la hidalguía se extendía por toda la geografía provincial, los linajes más relevantes residían en las localidades más importantes. La propia capital de la provincia y las antiguas sedes de las Órdenes Militares, como Almagro y Villanueva de los Infantes, son los lugares donde encontramos un mayor número de familias hidalgas con compras en la desamortización. En Almodóvar del Campo nos encontramos con la familia

42 Jerónimo López-Salazar Pérez, Estructuras agrarias..., pp. 254-309 y «Hidalgos de carne y hueso en la Mancha cervantina», en Pedralbes: Revista d'historia moderna, 25, 2005, pp. 51-102. También en Javier Donézar Díez de Ulzurrum, Riqueza y..., pp. 255-379.

${ }^{43}$ La mayor parte de los títulos que tan frecuentemente aparecen en el siglo XIX son de finales del XVIII y proceden de esta nobleza local como Conde de Montesclaros (1766), Conde de la Cañada (1789), Conde de Casa-Treviño (1789) y Conde de Casavaliente (1791). Más antiguo es el de Conde de las Cabezuelas (1690).

44 Ángel Ramón del Valle Calzado, «La consolidación de la pequeña nobleza rural manchega en la transición al régimen liberal: el caso de los Rosales», en Ciudadanos y familias. Identidades socioculturales en evolución durante el Antiguo Régimen (siglos XVII$X I X)$, Universidad de Valladolid, Valladolid, en prensa.

45 José María Barreda Fontes, Caciques y electores..., pp. 193-246. 
Salido y Corchado; en Almagro a los Ceballos y los Rosales; en Chillón, los Márquez de Prado; en Ciudad Real los Maldonado, los Medrano, los Muñoz y los Treviño; en Manzanares, los Enríquez de Salamanca y los García-Noblejas; en Campo de Criptana, los Baíllo; en La Solana, los Antolinez de Castro y los Jaraba y, por último, en Villanueva de los Infantes, los Ballesteros, los Melgarejo y los Fontes. Una fracción significativa de la nobleza local no sólo se mantuvo sino que logró encaramarse a la elite local en la transición al régimen liberal. Supieron adaptarse, conservar y ampliar su ya de por si importantes patrimonios. La Revolución Liberal, en su conjunto y con ella la desamortización, fue para ellos una vía de ascenso social. Muchos de estos hidalgos intuyeron que el liberalismo era el instrumento que les iba a facilitar su definitivo arraigo como una elite que, por fin, podría sobrepasar el marco local. Y por esta razón no sólo no lo combatieron, con unas pocas excepciones, sino que lo apoyaron inequívocamente ${ }^{46}$.

\subsection{Los excluidos: el campesinado}

Frente a los anteriores, los pequeños propietarios y los jornaleros apenas participaron. El número de labradores que compró es significativo (217, el $13 \%$ ), lo que demuestra que si tuvieron interés en participar en la desamortización ${ }^{47}$, pero sólo pudieron adquirir pequeñas fincas, dado que sus porcentajes de inversión y adquisición ( 1,0 y $2,4 \%$ respectivamente) son muy modestos. Tienen una mayor presencia en los pequeños municipios donde la competencia de grupos sociales más poderosos era menor. Prácticamente todos son pequeños compradores y sólo cuatro superan la barrera de los cincuenta mil reales de inversión. A nivel territorial existe cierto equilibrio tanto en el número de labradores, grado de inversión y extensión adquirida sin distinción entre comarcas más o menos latifundistas.

46 Ángel Ramón del Valle Calzado, «Desamortización eclesiástica y cambio social en La Mancha, 1836-1854», en Sociedad y Utopía 5, 1995, pp. 47-70 y José Antonio Inarejos Muñoz, La Revolución de 1854 en la España rural. El Bienio Progresista en Ciudad Real (18541856), Instituto de Estudios Manchegos, Ciudad Real, 2010, pp. 21-38.

47 «Labrador u hortelano» define al pequeño propietario de tierras, que las explotaba directamente con el apoyo de los miembros de la familia y que sólo de manera coyuntural acude a la mano de obra jornalera. 
Cotejando sus cuotas impositivas y su posición entre los mayores contribuyentes, nos encontramos que el $60 \%$ tenía derecho al voto y pagaba una contribución superior a 25 pesetas, pero sólo siete tienen una cuota superior a las 300 pesetas y sólo uno aparece entre los tres primeros contribuyentes de su población. La cuota por territorial de la inmensa mayoría de estos labradores se sitúa entre las 25 y las 100 pesetas. En conclusión, pensamos que, salvo contadas excepciones, los labradores que compraron formaban una capa intermedia entre los vecinos cuyo patrimonio no les daba derecho al voto y la capa de medianos y grandes propietarios. Una especie de clase media-baja de propietarios que, en ocasiones y en pequeñas poblaciones, llegaban a compartir espacios de poder local con ellos. Dado el nivel de sus compras queda demostrado que sólo pudieron beneficiarse de la desamortización marginalmente. La creación de sociedades de compra podría haber sido un mecanismo para acceder a la propiedad desamortizada, pero, en esta provincia, fue poco efectivo. La extensión adquirida por ellas se reduce, descontando el efecto de la Sociedad de Almodóvar del Campo, a 11.433 hectáreas, aunque allí donde se formaron se produjo, en mayor medida, un reparto de la tierra como en las localidades de Carrión, Torralba y Piedrabuena ${ }^{48}$.

Por otro lado es llamativa la escasa presencia de arrendatarios y jornaleros. El caso de los arrendatarios es complejo, pues no es una denominación muy usada en las fuentes. Sólo 5 compradores aparecen definidos como arrendatarios y cuatro invierten cantidades muy exiguas, que no llegan a superar los diez mil reales de inversión. Entre todos superaron escasamente las 200 hectáreas con una inversión de poco más de ciento sesenta mil reales. Los arrendatarios podrían ser un grupo social con gran interés en comprar y convertirse en propietarios, pero poco podemos decir al respecto. Seguramente muchos arrendatarios están ocultos dentro del grupo de los propietarios y de los labradores y sería arriesgado lanzar cualquier conclusión sobre su peso real. Por su parte, la presencia de los jornaleros es testimonial. Han aparecido 33 jornaleros como compradores. Adquieren 461 hectáreas en las que gastan ciento ocho mil reales. Además las búsquedas en el Boletín Oficial de la Provincia han sido infructuosas.

48 Ver Ángel Ramón del Valle Calzado, «La desamortización de la tierra en Torralba», en M. Romero Fernández y Francisco Alía Miranda, Historia de Torralba de Calatrava, Ayuntamiento, Torralba, 2005, pp. 79-94 y «La desamortización de la tierra en Piedrabuena», en F. Alía Miranda (coord.), Entre la cruz y Miraflores. Piedrabuena, espacio histórico y natural, Ayuntamiento, Piedrabuena, 2003, pp. 276-277. 
Parecen ser individuos sin historia. En el caso de la provincia de Ciudad Real, el proletariado rural no pudo acceder a las tierras desamortizadas ni la desamortización favoreció, en este caso, concreto, el acceso del campesinado a la tierra lo que no es óbice para que el acceso de los campesinos a la propiedad se hiciera por otras vías diferentes: compra de tierras, apropiación de comunes, etcétera.

El censo electoral de 1911 nos presenta un cuadro bastante aproximado de la sociedad rural tras la desamortización. El $72 \%$ de los electores son agrarios y estos se reparten entre un 7,3\% de propietarios, un $19,2 \%$ de labradores y un $73,5 \%$ de jornaleros. El pequeño propietario no ha desaparecido y está presente tanto en las comarcas latifundistas como minifundistas, pero, en general, estamos hablando de individuos con pequeñas parcelas y muy cercanos a los jornaleros, sobre todo, en las zonas latifundistas. Habría que investigar la naturaleza y el origen de la pequeña propiedad en relación a otras medidas de la reforma agraria liberal, pero lo que es evidente es que la desamortización no promovió un crecimiento de la misma, y si puso las bases de una sociedad rural extremadamente desigual. No olvidemos, por ejemplo, que zonas minifundistas como La Mancha presentan altísimas tasas de jornaleros en ese mismo censo. Así en Alcázar de San Juan los jornaleros suponen el $86,3 \%$ de los electores agrarios, en Tomelloso el 87,6 \% o en Valdepeñas el $87,9 \%$.

\subsection{La Burguesía local}

De los subgrupos que lo forman sobresale el de las profesiones liberales. Dentro de la amplitud profesional destaca el protagonismo de los abogados, que aportan prácticamente la mitad de las compras realizadas por todos los profesionales liberales. Junta a estos encontramos a

49 Para un examen preciso de esta estructura ver Ángel Ramón del Valle Calzado, «Los orígenes del conflicto. El problema de la tierra en Castilla-La Mancha», en Francisco Alía Miranda y Ángel Ramón del Valle Calzado (coords.), La Guerra Civil en Castilla-La Mancha, setenta años después, Universidad de Castilla-La Mancha, Cuenca, 2008, pp. 189-234, pp. 201-205. También podemos encontrar pruebas de esta sociedad desigual en el estudio realizado en base al Catastro de 1910 por María Paz Ladrón de Guevara Flores, Ciudad Real en el primer tercio del siglo XX (tierra, propiedad y cultivos, 1900-1930), Instituto de Estudios Manchegos, Ciudad Real, 1988. 
algunos procuradores, notarios y registradores de la propiedad, que conocían a la perfección el mercado de la tierra. En relación al total, los individuos relacionados con las leyes y su aplicación forman el grueso de las profesiones liberales. Le siguen los relacionados con la sanidad. Médicos, farmacéuticos y veterinarios forman un conjunto con cierto protagonismo y significativas compras. De todos ellos sobresalen las compras de treinta de ellos, que se quedan con la totalidad de la tierra adquirida por el grupo (el $91 \%$ ). Estamos, por tanto, ante un grupo bastante desequilibrado entre una mayoría de compradores modestos y otro, más minoritario, pero que aprovecha el proceso desamortizador a fondo y que les permite a algunos de ellos entrar en la lista de los cincuenta mayores contribuyentes de la provincia de 1875. Se trata de los abogados Julián Zaldívar Carrillo y Lorenzo Fernández-Yañez Nova pero, salvo contadas excepciones, no suelen encontrarse entre los mayores contribuyentes de sus respectivas poblaciones. Por el contrario, si participan activamente en la política local. Bastantes lograron un escaño en la Diputación Provincial ${ }^{50}$ y es muy usual encontrar a estos profesionales ocupando puestos políticos locales como alcaldías, concejalías, vocales asociados o jueces de paz. Se percibe, en este sentido, una clara integración de los mismos en las elites locales. Podemos decir que este grupo es bastante significativo, pues engloba a una serie de profesionales liberales que utilizaron la desamortización para consolidar su posición social y económica. La combinación del prestigio social del título y de la propia actuación profesional en ámbitos locales con la adquisición de un patrimonio rústico, de una mayor o menor envergadura, les convierte en elementos claves dentro de las elites locales, donde jugaron un papel relevante.

De menor importancia es el subgrupo de los comerciantes e industriales. No obstante, el seguimiento social-político de sus trayectorias nos descubre que están bien posicionados económicamente y aparecen integrados en las elites políticas locales. Dos de ellos (Juan Manuel Almagro y José Escobar y Vieja) lograron encaramarse a la lista de mayores contribuyentes provinciales de 1875 . La mayoría de estos comerciantes e industriales están ligados a la producción agraria o al mercadeo de productos de primera necesidad. El proceso de acumulación de capital está ligado,

${ }^{50}$ Es el caso de la familia Fernández Yañez y de otros tantos (José Cendrero Díaz, Nicasio Gómez, Manuel José Maján, Manuel Naranjo, Juan Inza, León de León, Antonio García, Noberto Urrutia, José Cendrero Rubio, entro otros). 
por tanto, a la comercialización y especulación en granos, a los préstamos a labradores y arrendatarios, al arrendamiento de algunos impuestos a nivel local o al abastecimiento de productos de consumo básicos. En ocasiones representan los intereses de compañías nacionales de seguros, de minas o de transporte en la provincia. El capital obtenido en sus negocios se derivó en parte y en algunos casos totalmente hacia la inversión en bienes raíces como las tierras desamortizadas, dando lugar a una reconversión de la segunda generación. Muchos de los hijos y herederos aparecen calificados profesionalmente no ya como comerciantes sino como propietarios. Este proceso no es nuevo, pues es muy similar a la trayectoria de la burguesía mercantil en espacios relativamente cercanos ${ }^{51}$. El resultado final es el debilitamiento de la burguesía comercial ya de por si escasa, que viene a reconvertirse en parte en burguesía agraria, abandonando así sus orígenes.

Por su parte, el peso de los funcionarios y militares provinciales es muy modesto. Los que más participaron fueron los secretarios de ayuntamientos. Económicamente son más modestos pues no ocupan posiciones relevantes entre los mayores contribuyentes ni a nivel local ni provincial. Tampoco tienen un excesivo protagonismo político, lo que podemos explicarlo por el hecho de que trabajan en la propia administración como funcionarios. Sólo en dos casos llegaron a la Diputación Provincial.

\subsection{Desamortización, elites locales, caciquismo}

Los últimos estudios nos revelan una situación compleja, que renovaba las visiones que se tenían de los poderes locales en el siglo XIX y de la naturaleza del sistema político de la Restauración ${ }^{52}$. En la España del siglo XIX la propiedad fue la principal vía de acceso al poder local. El sistema canovista ubicó a los mayores contribuyentes en el centro del esce-

51 Cosme Jesús Gómez Carrasco, Familia y capital comercial en la Castilla meridional. La comunidad mercantil en Albacete (1700-1835), Silex, Madrid, 2009, p. 297-308.

52 Jesús Millán García Valera, «Los poderes locales en la sociedad agraria: una propuesta de balance», en Historia Agraria, 22, 2000, pp. 97-110 y Juan Pro Ruiz, «las elites..., pp. 47-69. Podemos encontrar un resumen de la evolución de la historiografía española sobre el caciquismo en Salvador Cruz Artacho, «Clientes, clientelas y política en la España de la Restauración (1875-1923)», en Ayer, 36, 1999, pp. 105-130. 
nario a través de las juntas de asociados y de otros múltiples mecanismos. De esta manera las compras en el proceso desamortizador facilitaban el ascenso o consolidación dentro de los mayores contribuyentes y esto, a su vez, permitía el control del poder local ${ }^{53}$.

Por esta razón la desamortización fue tan importante a la hora de configurar las elites locales que dominarán la Restauración y lo hizo en dos niveles. El primero está formado por aquellos que forman las familias políticas más destacadas, en la mayor parte de las veces, miembros de la nobleza local y destacados compradores de bienes nacionales. Y el segundo nivel y en íntima conexión con el primero, un segmento de propietarios más modestos, pero que dominara los espacios de las pequeñas localidades, entre los que también solemos encontrar a beneficiarios de la desamortización. Sólo algunos miembros de la burguesía local no agraria lograrán incrustarse en algunos de estos dos niveles, preferentemente el primero, pero curiosamente serán también significados compradores. Recordemos además que el conjunto de los primeros mayores contribuyentes de cada localidad, 93 en total, 52 fueron compradores, casi un $70 \%$.

Esta misma relación aparece si se analiza la lista provincial de mayores contribuyentes de 1875 . De los 50 mayores contribuyentes, 36 lo son en parte gracias a la desamortización. Aparecen nueve compradores madrileños (Francisco de las Rivas, Aureliano Berruete, Conde de Campomanes, Francisco Pérez Crespo, José Ceriola, Antonio de Lara, Juan Alberto Casares, José Oliver Matheu o Rafael Sevillano) y nada menos que 23 compradores de la nobleza local (Conde de las Cabezuelas, Luís Muñoz, José María Melgarejo, José Medrano, Diego Andrés Ballesteros, Juan Rosales, Ramón Melgarejo, Conde de la Cañada, Manuel Maldonado, Gabriel Jaraba, Valeriano López Torrubia, Marqués de Casa Treviño, José Antonio Marañón, Juan Tomás de Frías, José Barnuevo, Francisco Jaraba Merino, Tomás Jaraba, José Enriquez Antolinez, Francisco Jaraba Antolinez, José Maldonado, Diego Antonio Ballesteros, Francisco Laso Salido y Lorenzo Fernández Yañez). Estos apellidos coin-

53 Buena parte de los estudios locales demuestran que los mayores contribuyentes de la localidad ocupan el poder político (Isabel Moll y Pere Salas, «Las pequeñas elites agrarias y su participación en la vida política durante la segunda mitad del siglo XIX», Ayer, 48, 2002, pp. 159-184, p. 175 y Javier Moreno Luzón, «La historiografía sobre las elites en la España liberal», en Rafael Zurita y Renato Zamurri (eds.), Las elites en España e Italia (1850-1922), Universitat de Valencia, Valencia, 2008, pp. 27-42, p. 39. 
ciden con las familias políticas de la Restauración que coparon tanto el parlamento como la Diputación Provincial durante la Restauración ${ }^{54}$, a los que debemos sumar los parlamentarios que proceden de la burguesía madrileña, que también tendrán influencia política en los distritos donde eran grandes propietarios.

Estudios micro no han hecho sino confirmarlo. Es el caso de la familia hidalga de los Rosales en Argamasilla de Calatrava, que se instalaron aquí en el siglo XV. Pues bien a través de diversas estrategias (servicios a la Corona, control del poder local, política matrimonial...) fueron consolidando su posición social hasta que en el siglo XIX engrandecieron su ya de por si importante patrimonio con importantes compras en la desamortización y establecieron un sólido cacicato en la Restauración que perduró incluso hasta la época republicana ${ }^{55}$. En otra población cercana, Calzada de Calatrava, el cacicato estuvo dirigido por la familia Maldonado, siempre los primeros contribuyentes, cuyas adquisiciones en la desamortización fueron más modestas que en el caso anterior, lo que prueba que no sólo fue este proceso la vía para la creación de las bases patrimoniales. Lo que nos interesa de este caso es que el segundo nivel de caciques también participaron en la desamortización: las familias Casado, Real, Serrano y Sánchez-Villalón. Todas ellas ocupan el poder local y constituyen la base de apoyo de la familia Maldonado. Además en esta localidad compraron dos banqueros madrileños, Jaime Ceriola y Francisco de las Rivas, posteriormente Marqués de Mudela. El hijo del primero, José Ceriola y de las Rivas fueron diputados por el distrito en varias ocasiones durante la segunda mitad del siglo XIX. Las dos familias (Ceriola y de Las Rivas) mantuvieron largo tiempo sus posesiones aquí y de hecho fueron objeto de colectivización durante la Guerra Civil ${ }^{56}$.

${ }^{54}$ Una lista pormenorizada se puede ver en José María Barreda, Caciques..., pp. 195204.

55 Ángel Ramón del Valle Calzado, «La consolidación de la pequeña nobleza rural manchega en la transición al régimen liberal: el caso de los Rosales», en Ciudadanos y familias. Identidades socioculturales en evolución durante el Antiguo Régimen (siglos XVIIXIX), Universidad de Valladolid, Valladolid, 2014, pp. 274-286.

56 Todos los datos han sido obtenidos de Francisco Rodríguez García y José Antonio Camacho Horta, Oligarquía y elecciones en Calzada de Calatrava (1833-1931), Biblioteca Oretania, Puertollano, 2011, especialmente pp. 39-56 y Andrés Mejia Godeo, La desamortización en el siglo XIX. Calzada de Calatrava, Intuición editorial, Ciudad Real, 2001, pp. 282-298. 
En definitiva, la desamortización favoreció la base patrimonial en que se basó el dominio de las familias políticas en los diferentes niveles del entramado de la Restauración. La vinculación entre desamortización y redes caciquiles en esta provincia está probada, aunque evidentemente su poder patrimonial no proviene exclusivamente de la desamortización, pero si fue uno de los factores más relevantes.

\section{Los que más llaman la atención: la burguesía de negocios madrileña}

Hemos conseguido ubicar profesionalmente a buena parte de los compradores madrileños (103 de 151). En total invirtieron 75.902 .785 reales y se quedaron con 221.583 hectáreas. En la tabla 5 se observa su composición interna. Sobresale el protagonismo de la burguesía de los negocios madrileña, que agrupa a un muy relevante grupo de compradores no por número sino por la amplitud de sus compras. Sus inversiones son algo menores que las del grupo de los propietarios, pero hemos de considerar que estamos hablando de 29 compradores. De media realizan una inversión superior al millón trescientos mil reales y adquieren más de tres mil setecientas hectáreas. En parte asimilable socialmente a estos y con algunos rasgos comunes estaría el grupo de los comerciantes e industriales, aunque sus compras fueran menores. En conjunto vendrían a representar a la nueva burguesía que se desarrolla al calor de la revolución liberal y de la implantación del modelo económico liberal en España. El otro gran grupo sería el de la burguesía profesional o burocrática, en la que podemos englobar a profesionales liberales, funcionarios, políticos, militares y eclesiásticos. Aunque sus compras son menores también configuran un sector de la burguesía madrileña que también optó por invertir en tierras desamortizadas. En algunos casos como el de los políticos y militares existen conexiones entre ellos y el de los banqueros capitalistas, pues no se tratan, en ningún caso, de grupos estancos sin relación alguna. Finalmente nos encontramos ante otro sector que se califica profesionalmente como «propietario», concepto aún más indefinido aplicado a individuos que residen en Madrid. No sabemos con exactitud si ese atributo profesional se lo atribuyen por su condición de propietarios de bienes rústicos o urbanos, o ambos conjuntamente, o si se refieren a que la parte más significativa de sus ingresos provienen de la explotación de su patrimonio personal y no de sus actividades profesionales o comerciales. Sea como fuere los propietarios con residencia en Madrid es un grupo potente en las compras desamortizadoras. 
En el caso de esta provincia la presencia de una significada fracción de la burguesía de los negocios madrileña no es un tópico, es una realidad. Está formada por veinte banqueros, cuatro agentes de cambio y bolsa, tres agentes de negocios y dos sociedades anónimas. La mayoría están íntimamente relacionados entre sí en múltiples empresas con intereses comunes y su ubicación política inicial es coyuntural, puesto que muchos de los banqueros ligados al progresismo en las primeras décadas liberales se fueron desligando del mismo y aproximando al liberalismo conservador conforme avanzaba la centuria. Sobresalen los banqueros que pertenecieron al entorno financiero de Mendizábal, pues formaron un círculo de hombres de negocios que apoyaron la política del partido progresista en los años treinta. Además de Francisco de las Rivas, encontramos a miembros de estas cinco familias: Safont, Ceriola, Sevillano, Bárcenas y Cano. También algunos banqueros afines al partido moderado como Manuel Salvador López o el matrimonio formado por Antonio de Lara y Eulalia Fontanellas, junto con otros políticos moderados como Juan Bravo Murillo o como Alejandro Oliván. Otros estaban ligados a las elites antillanas como Juan Francisco Chacón, Blas Villate Lahera o Juan Alberto Casares y aparecen también algunos empresarios como Abelardo de Carlos o Carlos Eizaguirre, y otros que se califican como propietarios entre los que sobresale Aureliano de Berruete Larrinaga. Y entre los militares de prestigio emerge la figura del General Juan Prim, que también figura en la nomina de compradores. Por lo tanto el negocio desamortizador constituyó para este grupo de prohombres una parte sustancial en su estrategia inversora.

Entre estos hombres de negocios encontramos cierta diversidad, pero también rasgos comunes. Por lo general, llegaron a Madrid a lo largo de las primeras décadas del siglo XIX y aquí consolidaron su posición social y económica gracias a las necesidades del Estado liberal, que afrontaba una dura y larga guerra civil. Los créditos al Estado y los suministros al ejército o contratas de servicios públicos fue el mecanismo más usual para redondear una gran fortuna. Prácticamente todos ellos responden al prototipo del burgués que se enriquece en una sola generación. Fueron una especie de banqueros premodernos. Prestaban dinero, especulaban en bolsa, compraban deuda pública pero, sobre todo, crecían gracias a las suculentas contratas de suministros al Estado. Sus compras en la desamortización suponen un giro de las actividades propiamente bancarias a las agrarias, pero sin abandonar sus anteriores negocios. Buscaron en la tierra prestigio social y un patrimonio que facilitara su ascenso a la nobleza o su llegada 
al Senado, así como una nueva ubicación en las listas de mayores contribuyentes, donde pasarán a compartir espacios con la nobleza de cuna, la nobleza local y algunos propietarios. De banqueros a propietarios, de progresistas a moderados, de burgueses a nobles, he aquí un recorrido tipo de estos protagonistas ${ }^{57}$.

\section{Conclusiones}

Dos factores influyeron de manera significativa en el peso del mundo rural en la desamortización: el grado de urbanización de las poblaciones y el tamaño de la propiedad vendida. A mayor urbanización y menor tamaño de las fincas, más presencia de compradores rurales. Dado que en esta provincia tenemos comarcas que presentan diferentes modelos en cuanto a la estructura de la propiedad y de poblamiento, nos encontramos con un gran protagonismo de los compradores urbanos, sobre todo madrileños, en las zonas latifundistas y de escaso poblamiento donde se pusieron en venta grandes fincas, mientras en las comarcas con una menor presencia de la gran propiedad el mundo rural tuvo una mayor participación. Por lo tanto, no podemos rechazar las afirmaciones de la historiografía desamortizadora de los años setenta que insistía en la relevancia de los compradores urbanos madrileños pero, por otro, tampoco lo apuntando en las últimas aportaciones que subrayan la participación de grupos sociales rurales, que no quedaron excluidos del proceso desamortizador. Esto no quiere decir que los sectores más bajos del campesinado se favorecieran de la desamortización. La presencia de jornaleros es testimonial. La de labradores y pequeños-medianos propietarios también. Para todos ellos la desamortización no le supuso un cambio a mejor de su status económico. No olvidemos que el $70 \%$ de los compradores se repartieron 16.000 hectáreas, mientras un pequeño y selecto grupo de compradores (177) se quedaron con 500.000 hectáreas. Ni hay incremento sustancial de propietarios ni se crea una clase media rural como bien sucedió en Francia.

57 José Antonio Piqueras Arenas, «Negocios y política en el siglo XIX español», en J. PANIAGUA y J.A. PIQUERAS ARENA (eds.), Poder económico y poder político, Instituto de Historia Social, Valencia, 1998, pp. 11-52 y Ángel Ramón del Valle Calzado, «Entre les finances et la vigne. L'emporium vinicole du Marquis du Mudela dans La Mancha», en La construction de la grande propriétè viticole en France et en Europe, XVI-XXe siècles, Ed. Féret, Burdeos, 2015, pp. 29-43. 
¿Quiénes formaban ese selecto grupo? Además de un sector concreto de la burguesía madrileña, por el segmento medio-alto de los «propietarios» y por parte de la nobleza local. Junto a ellos se incrustan algunos miembros de la burguesía local y algunos profesionales liberales. La elite agraria que surge con la desamortización integra elementos burgueses como banqueros madrileños, profesiones liberales, comerciantes, industriales y funcionarios, pero también elementos enraizados con el Antiguo Régimen. Encontramos así en esta provincia dos elementos particulares que no suelen ser usuales en otras provincias: el peso de la burguesía madrileña y de la nobleza local ${ }^{58}$. La aparición de grupos hidalgos parece indicarnos que Herr no iba demasiado desencaminado al comprobar el papel de la desamortización de Godoy como mecanismo de integración de la hidalguía del Antiguo Régimen en la elite que nace con la revolución liberal ${ }^{59}$. En este caso el modelo manchego consolida esta hipótesis y la de Germán Rueda cuando sostiene que los hacendados del Antiguo Régimen, los propietarios rurales y la burguesía de los negocios (local y foránea) constituyen el núcleo central de la burguesía agraria de la Restauración creada, en parte, por la desamortización ${ }^{60}$. Un mero repaso a las sagas caciquiles durante la Restauración permite comprobar la evidente correlación entre caciques (locales, comarcales y provinciales) y los compradores de bienes desamortizados. Caciquismo, dependencia de Madrid y desamortización van unidos indisolublemente en este caso concreto de la España interior.

¿Se puede extrapolar este modelo al resto de la región? El caso de Ciudad Real se diferencia tanto en la relevancia de la burguesía madrileña como en el protagonismo de la nobleza local ${ }^{61}$. La primera no aparece en Cuenca, y aunque no está ausente en las de Albacete, Guadalajara y Toledo sus compras tienen menos peso. Algo similar ocurre con la nobleza local, ya que su presencia en el resto de provincias es mucho menor. Si coinciden, por el contrario, en cuanto al importante papel de los propietarios de tierras, aunque en este último caso, en Ciudad Real y Albacete sobresalen los grandes propietarios, mientras en Cuenca, Guadalajara y To-

\footnotetext{
58 Félix Castrillejo Ibáñez, «Transformaciones..., pp. 250-251.

59 Richard Herr, «Hidalguía y desamortización bajo Carlos IV», en Desamortización y Hacienda Pública, Madrid, 1986, pp. 463-478.

${ }^{60}$ Germán Rueda, «El proceso..., p. 210.

${ }^{61}$ Los datos referentes a las diferentes provincias se han extraído de las monografías citadas en la nota 7 .
} 
ledo los pequeños y medianos propietarios tuvieron más peso, los grupos bajos del campesinado si participaron más. Lo sucedido en Ciudad Real se parece, a nuestro entender, más al modelo extremeño, seguramente porque ambos espacios se asemejan en el alto grado de concentración de la propiedad desamortizada, que condicionó la personalidad de los compradores $^{62}$.

En definitiva, en el caso de Ciudad Real ni el mundo rural vivió de espaldas la desamortización ni la presencia de la burguesía madrileña es un tópico. Lo que tampoco parece conveniente a la vista de este caso es intentar minusvalorar el papel de este último grupo para intentar subrayar una mayor participación del campesinado o esquivar la realidad tozuda de los datos que evidencian la importancia de la reforma agraria liberal en la formación de la base patrimonial de las elites locales de la Restauración, al menos en algunas regiones. Lo que queda claro también es la necesidad de particularizar los diferentes modelos. No existe un solo modelo para la España interior. Lo sucedido en Ciudad Real se diferencia aún incluso de otras provincias que a priori presentan similitudes como Albacete o Toledo, y mucho más aún con los modelos de las provincia al norte del Tajo (Cuenca y Guadalajara) con lo que hemos de insistir en la necesidad de procurar delimitar las generalizaciones sin contrastar y la necesidad de afrontar el estudio de la desamortización desde perspectivas microhistóricas.

62 Para lo sucedido en Cáceres ver Juan García Pérez, Las desamortizaciones..., p. 191. 